\author{
Ostap Ivashkiv ${ }^{1}$, Jacek Namiesnik ${ }^{2}$, Olena Astakhova ${ }^{1}$, Olena Shyshchak ${ }^{1}$ \\ and Michael Bratychak ${ }^{1}$
}

\title{
SYNTHESIS AND APPLICATION OF OLIGOMER WITH HYDROXY GROUPS BASED ON PEROXY DERIVATIVE OF ED-24 EPOXY RESIN AN D POLYTHF-2000 OLIGOETHER
}

\author{
1Lviv Polytechnic National University, \\ 12, St. Bandera str., 79013 Lviv, Ukraine; mbratych@ polynet.Iviv.ua \\ ${ }^{2} \mathrm{G}$ dansk University of Technology, \\ 11/ 12 G. N arutowicza str., 80233 Gdansk, Poland
}

Received: September 28, 2014 / Revised: December 18, 2014 / Accepted: January 25, 2015

(C) Ivashkiv O., Namiesnik J., Astakhova O., Shyshchak O., Bratychak M., 2015

\begin{abstract}
New oligomer with peroxy, primary and secondary hydroxy groups has been synthesized on the basis of peroxy derivative of ED-24 epoxy resin (PO) and PolyTHF-2000 oligoether according to the developed procedure. The effect of the catalysts nature and amount, temperature and process time on the reaction rate has been studied. Benzyltriethylammonium chloride, potassium hydroxide, 1,4-diazobicyclooctane and the mixture composed of benzyltriethylammonium chloride and $\mathrm{KOH}$ (molar ratio 1:1) were used as the catalysts. The structure of the synthesized oligomer has been confirmed by the chemical and IR-spectroscopic methods. The synthesized oligomer may be used as an active additive for the production of polymeric films based on ED-20 industrial epoxy resin and TGM-3 oligoesteracrylate.
\end{abstract}

Keywords: epoxy resin, oligoether, kinetics, peroxide, hydroxy group, IR-spectroscopy, cross-linking.

\section{Introduction}

Oligomers with various functional groups are widely used as active additives to the polymeric mixtures
$[1,2]$. The compounds with the functional groups capable to simultaneously react via radical and condensation mechanisms are of special interest [2]. The analysis of literature data shows that epoxy resins are more often used for the synthesis of oligomers with functional groups different by their nature [3-5]. Such choice is connected with the fact that they contain reactive epoxy groups allowing to introduce peroxy [3], carboxy [4] and methacrylate [5] groups into the resin structure via oligomer analogous conversions. While introducing the mentioned groups the secondary hydroxy groups are formed as a rule. They are less reactive compared with the primary hydroxy groups therefore they need high temperatures $-413 \mathrm{~K}$ and higher [4].

In this work we studied the synthesis of oligomer based on ED-24 epoxy resin and containing peroxy, primary and secondary hydroxy groups at the same time. In our opinion, the presence of peroxy and primary hydroxy groups allows to extend the possibility of functional compounds application as additives to the polymeric mixtures.

Generally, the synthesis of hydroxy derivative of ED-24 epoxy resin with free epoxy group (HPO) may be represented by Eqs. (1) and (2):

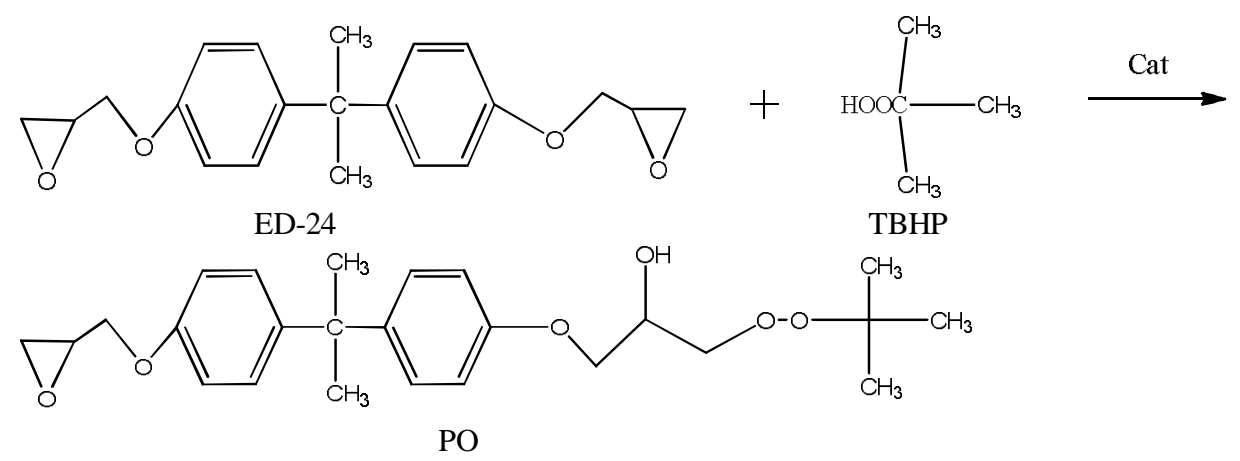




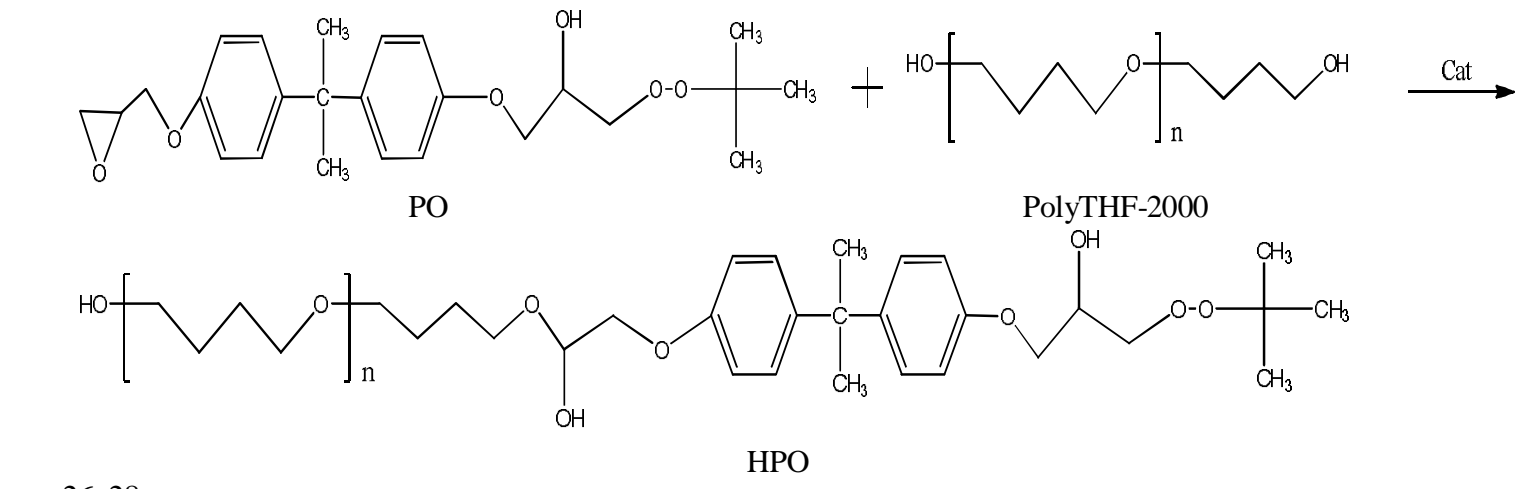

$n=26-28$

Peroxy oligomer (PO) obtained according to Eq. (1) is a known product and its synthesis on the basis of ED-24 resin and tert-butyl hydroxyperoxide (TBHP) is described in [6]. The reaction between PO and PolyTHF2000 oligoether is not described in the literature and we study it here.

\section{Experimental}

\subsection{M aterials}

ED-24 resin was obtained via interaction between bisphenol A and epichlorhydrine with the molecular mass $M_{n}$ of $340 \mathrm{~g} / \mathrm{mol}$ and epoxy number e.n. $24 \%$. TBHP was obtained according to the procedure described in [7] and after purification its characteristics were: $M_{n}=90 \mathrm{~g} / \mathrm{mol}$; active oxygen content $[\mathrm{O}]_{a c t}=4.2 \%$.

PO was synthesized on the basis of ED-24 resin and TBHP according to the procedure described in [6]. Its characteristics were: $M_{n}=420 \mathrm{~g} / \mathrm{mol} ;$ e.n. $=10.5 \%$, $[\mathrm{O}]_{a c t}=3.3 \%$. PolyTHF- 2000 was purchased from BASF Canada Inc. and was used as received with $M_{n}$ of $1950 \mathrm{~g} / \mathrm{mol}$; hydroxy number of $54.7 \mathrm{mg} \mathrm{KOH} / \mathrm{g}$ and acid number of less than $0.05 \mathrm{mg} \mathrm{KOH} / \mathrm{g}$. The catalysts of Eq. (2) were: potassium hydroxide, benzyltriethylammonium chloride (BTEACh), 1,4-diazobicyclooctane (DABCO) and the mixture composed of BTEACh and $\mathrm{KOH}$ (molar ratio $1: 1)$.

The epoxy dianic resins ED-20 used for the cross-linking had $M_{n}=390 \mathrm{~g} / \mathrm{mol}$ and e.n. $=20 \%$. TGM-3 oligoesteracrylate had $M_{n}=280 \mathrm{~g} / \mathrm{mol}$. Polyethylene-polyamine (PEPA) was used as received without additional purification.

\subsection{Analysis M ethods}

The epoxy number was determined using back titration of the sample in the acetone + hydrochloric acid solution by $0.1 \mathrm{~N}$ alkali solution [8]. The active oxygen content in the initial PO and synthesized HPO was determined using the procedure described in [9]. IRspectroscopy was carried out using Specord M-80 spectrophotometer (Brucker, Germany). The samples were prepared as a film formed from oligomer solution in chloroform and applied over $\mathrm{KBr}$ plates.

\subsection{Kinetic Investigations}

PO with PolyTHF-2000 interaction was studied in a three-necked reactor equipped by a mechanical stirrer. Isopropyl alcohol was the reaction medium. The reaction proceeding was controlled by determination of epoxy groups concentration in the reaction medium according to [8].

\subsection{H PO Synthesis}

HPO synthesis was carried out in a three-necked reactor equipped with a mechanical stirrer, back condenser and thermometer. $25.0 \mathrm{~g}$ of PO dissolved in $50 \mathrm{ml}$ of isopropyl alcohol, $121 \mathrm{~g}$ of PolyTHF-200 dissolved in $200 \mathrm{ml}$ of isopropyl alcohol, $4.13 \mathrm{~g}$ of BTEACh dissolved in $2.75 \mathrm{ml}$ of water and $1.2 \mathrm{~g}$ of $\mathrm{KOH}$ dissolved in $1.53 \mathrm{ml}$ of water were loaded into the reactor. The mixture was heated to $323 \mathrm{~K}$ and was sustained under constant stirring for $25 \mathrm{~h}$. Then it was cooled to the room temperature and neutralized by $10 \%$ solution of acetic acid. Then $200 \mathrm{ml}$ of toluene were added, the mixture was washed till the neutral reaction and dried under vacuum at $343 \mathrm{~K}$ till the mass became constant. HPO in the amount of $137.68 \mathrm{~g}$ (yield 94.3\%) was obtained capable to dissolve in the organic solvents.

\subsection{H PO Cross-linking Properties}

HPO cross-linking activity was studied using polymeric mixture 1 and 2 (Table 1). 
Table 1

Composition of epoxy-oligomeric mixtures

\begin{tabular}{|l|c|c|}
\hline \multirow{2}{*}{ Component } & \multicolumn{2}{|c|}{ Component content in the mixture, wt \% } \\
\cline { 2 - 3 } & Mix 1 & Mix 2 \\
\hline Dianic resin ED-20 & 71.6 & 79.5 \\
\hline HPO & 7.9 & - \\
\hline TGM-3 & 7.9 & 7.9 \\
\hline PEPA & 12.6 & 12.6 \\
\hline
\end{tabular}

Polymeric mixtures were prepared by mixing the components till homogeneous viscous solution was obtained. It was applied over degreased glass plate of the standard size. The films were kept for $24 \mathrm{~h}$ at room temperature and then heated to 383 or $423 \mathrm{~K}$ for 15,30 , 45, 60 and $75 \mathrm{~min}$. The film formation was controlled by determination of gel-fraction content (Soxhlet apparatus, $10 \mathrm{~h}$, chloroform) and hardness (M-3 pendulum device).

\section{Results and Discussion}

\subsection{Kinetic Investigations}

Kinetic investigations of PO reaction with PolyTHF2000 (Eq. (2)) were carried out to establish the optimum conditions for HPO synthesis. To determine the amount of the catalyst under which the reaction would proceed with the sufficient rate, we investigated $15-30 \mathrm{~mol} \%$ of the catalyst relative to $1 \mathrm{~g}$-eq. of epoxy group. The investigated temperature range was $323-343 \mathrm{~K}$. The temperature increase above $343 \mathrm{~K}$ is undesirable because of partial decomposition of peroxy groups in the initial PO.

Using the catalysts BTEACh $(30 \mathrm{~mol} \%), \mathrm{KOH}$ (30 $\mathrm{mol} \%)$ or DABCO $(15 \mathrm{~mol} \%)$ the concentration of epoxy groups is not changed for $1.5 \mathrm{~h}$ (the reaction does not proceed) even at $343 \mathrm{~K}$. Other results were obtained using the catalytic mixture of BTEACh+KOH (molar ratio 1:1). With BTEACh and $\mathrm{KOH}$ amount of $30 \mathrm{~mol} \%$ in the mixture the epoxy groups concentration decreases already at $333 \mathrm{~K}$.

The effect of temperature on the reaction rate is illustrated in Fig. 1. It is well-known that the increase in temperature increases the reaction rate and effective rate constants. At $323 \mathrm{~K}$ the reaction rate is $1.64 \pm$ $\pm 0.17 \cdot 10^{-4} \mathrm{l} /(\mathrm{mol} \cdot \mathrm{s}) ;$ at $333 \mathrm{~K}-2.06 \pm 0.15 \cdot 10^{-4} \mathrm{l} /(\mathrm{mol} \cdot \mathrm{s})$ and at $343 \mathrm{~K}-2.68 \pm 0.22 \cdot 10^{-4} \mathrm{l} /(\mathrm{mol} \cdot \mathrm{s})$. The interpretation of calculated effective reaction rates in the Arrhenius coordinates (Fig. 2) allows to calculate the activation energy of the reaction between PO and PolyTHF2000 in the presence of BTEACh+KOH catalytic system. The activation energy is $22.6 \pm 2.8 \mathrm{~kJ} / \mathrm{mol}$.

Fig. 3 illustrates the reaction proceeding in time under the optimum conditions. At $323 \mathrm{~K}$ the complete exchange of epoxy groups for the fragments of PolyTHF-
2000 takes place after $25 \mathrm{~h}$. The obtained results allow to propose the procedure of HPO synthesis (Subsection 2.5). The obtained product is an amorphous compound of lightyellow color with $M_{n} 2370 \mathrm{~g} / \mathrm{mol}$ and [O] $]_{a c t} 1.03 \%$.

\subsection{IR-Spectroscopic Investigations}

IR-spectroscopic investigations were carried out to confirm the structure of the synthesized HPO. The spectrum of the initial PO was recorded for comparison. The obtained results are represented in Fig. 4. The absorp-

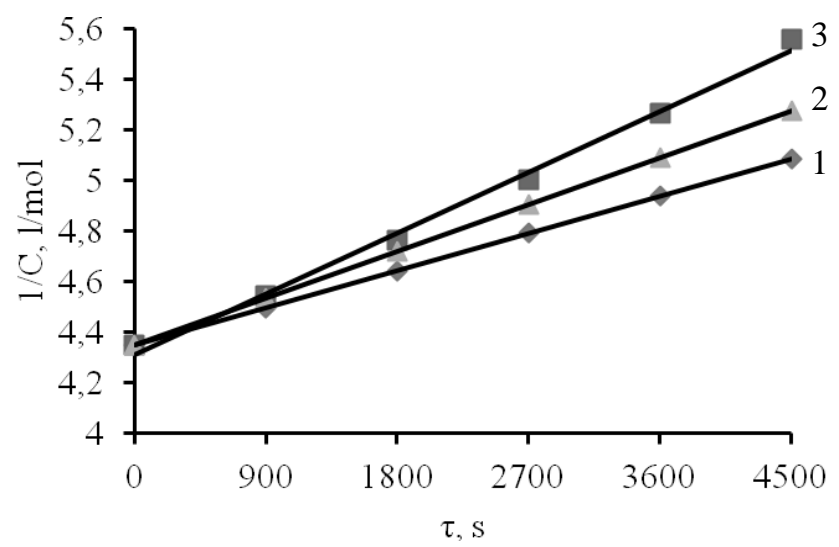

Fig. 1. Kinetic anamorphouses in the coordinates $1 / C$ - $\tau$ for the reaction between $\mathrm{PO}$ and PolyTHF-2000 in the medium of isopropyl alcohol at the temperatures (K) of: $323(1), 333$ (2) and 343 (3). Molar ratio BTEACh: $\mathrm{KOH}=1: 1$; BTEACh amount is $30 \mathrm{~mol} \%$ relative to $1 \mathrm{~g}$-eq. of $\mathrm{PO}$ epoxy group. Molar ratio PolyTHF-2000:PO = 1:1

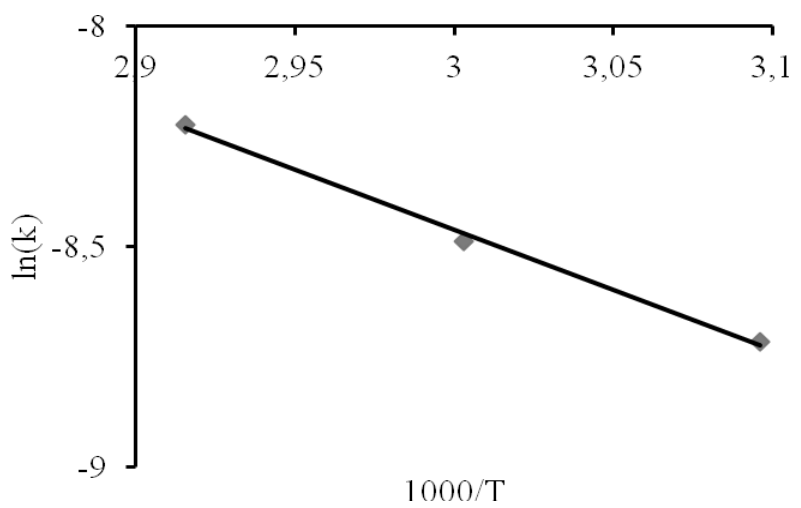

Fig. 2. Dependence of $\lg K_{e f}$ on $1000 / T$ for the interaction between PolyTHF-2000 and PO in the medium of isopropyl alcohol 


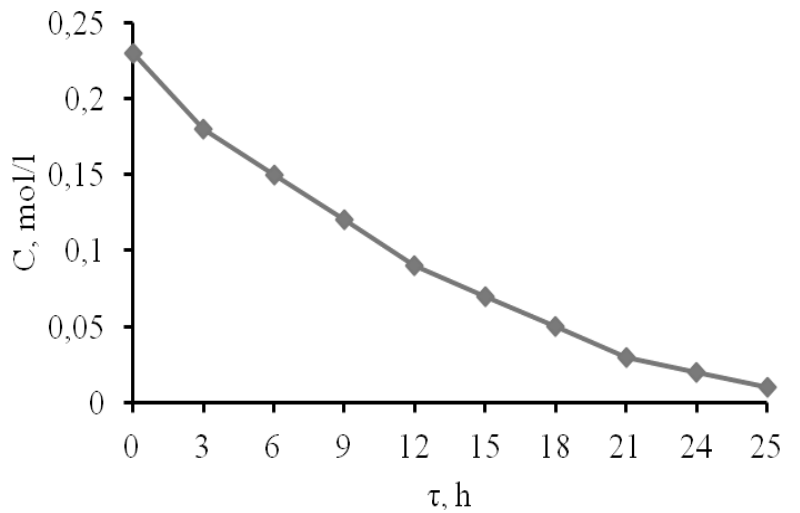

Fig. 3. Change of epoxy groups concentration $(C) v s$. reaction time $(\tau)$ for the reaction between PolyTHF and PO in the medium of isopropyl alcohol at $323 \mathrm{~K}$. Molar ratio

BTEACh: $\mathrm{KOH}=1: 1$; BTEACh amount is $30 \mathrm{~mol} \%$ relative to 1 g-eq. of PO epoxy group. Molar ratio PolyTHF-2000:PO = 1:1 tion band at $910 \mathrm{~cm}^{-1}$ corresponding to the epoxy ring stretching vibrations is observed in the spectrum of the initial PO (Fig. 4a). This band is absent in the spectrum of the synthesized HPO (Fig. 4b). It means that epoxy ring is opened and fragments of PolyTHF-2000 are adjoined to PO molecule. The increase in the absorption band intensity at $3448 \mathrm{~cm}^{-1}$ (typical of hydroxy group stretching vibrations) also indicates the bonding of PolyTHF-2000 to PO molecule and opening of the epoxy ring with the hydroxy group formation. The introduction of HPO of PolyTHF-2000 fragments is confirmed by the appearance of absorption band at $1248 \mathrm{~cm}^{-1}$ corresponding to the vibrations of $\left(\mathrm{CH}_{2}\right)_{\mathrm{n}}$ groups present in the initial PolyTHF-2000. The presence of $-\mathrm{O}-\mathrm{O}-$ bond in the synthesized HPO is vindicated by doublet of hemdimethyl vibrations at 1395 and $1368 \mathrm{~cm}^{-1}$ typical of $\mathrm{CH}_{3}$ $\mathrm{C}\left(\mathrm{CH}_{3}\right)_{2}-\mathrm{O}$ group.

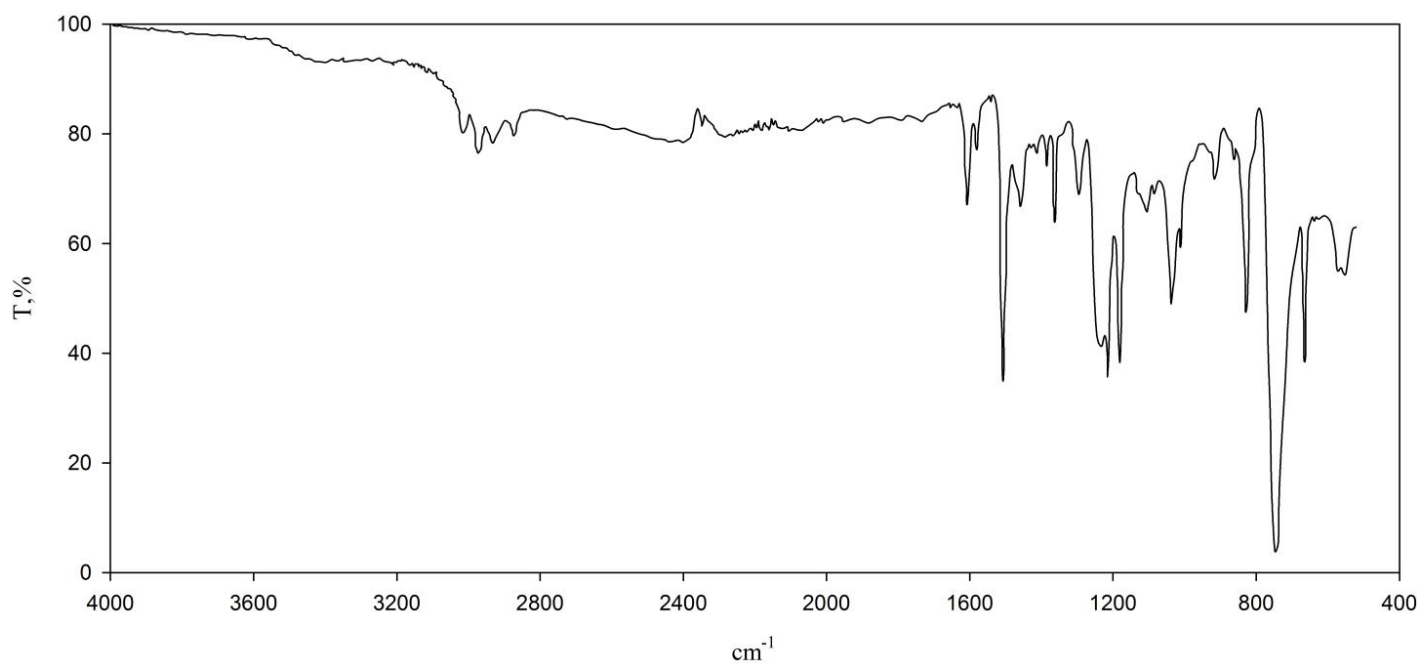

a)

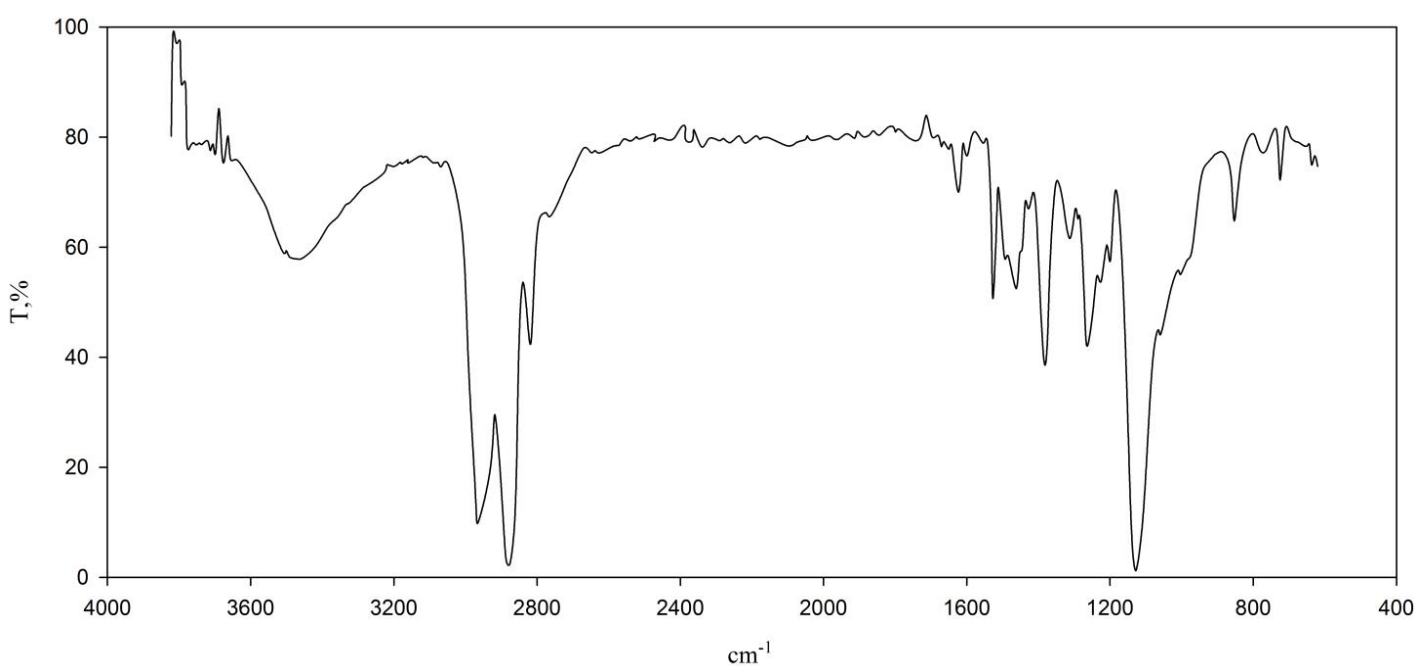

b)

Fig. 4. IR-spectra of PO (a) and HPO (b) 
Table 2

\begin{tabular}{|c|c|c|c|c|c|c|c|c|}
\hline \multirow{2}{*}{$\begin{array}{c}\text { Mixture } \\
\text { according to } \\
\text { Table 1) }\end{array}$} & \multirow{2}{*}{$\begin{array}{c}\text { Temperature, } \\
\mathrm{K}\end{array}$} & \multirow{2}{*}{ Index } & & \multicolumn{6}{|c|}{$\begin{array}{c}24 \mathrm{~h}, \\
\text { normal } \\
\text { conditions }\end{array}$} & & 15 & 30 & 45 & 60 & 75 \\
\hline \multirow{3}{*}{1} & \multirow{2}{*}{383} & $G$ & 44.1 & 67.4 & 71.6 & 73.6 & 76.3 & 77.2 \\
\cline { 3 - 9 } & \multirow{2}{*}{423} & $H$ & - & 0.21 & 0.25 & 0.44 & 0.47 & 0.58 \\
\cline { 3 - 9 } & & $G$ & 44.1 & 68.5 & 76.8 & 98.5 & - & - \\
\hline \multirow{2}{*}{2} & 423 & $G$ & 71.0 & 79.1 & 86.6 & 87.6 & 92.1 & 92.1 \\
\cline { 3 - 9 } & & $H$ & 0.26 & 0.71 & 0.82 & 0.87 & 0.87 & 0.87 \\
\hline
\end{tabular}

Notes: $G$ - gel-fraction content, $\% ; H$ - films hardness, rel. units

\subsection{Cross-linking of Epoxy-Oligomeric Mixtures in the Presence of HPO}

The epoxy-oligomeric mixtures were cross-linked in the presence of HPO according to the procedure described in Subsection 2.6. The investigated mixture consists of the industrial dianic epoxy resin ED-20, oligoesteracrylate TGM-3 and the synthesized HPO. PEPA is a hardener (Mix 1, Table 1). The mixture without HPO (Mix 2, Table 1) is taken for the comparison.

The experimental results are represented in Table 2.

After cross-linking the films based on Mix 1 at the room temperature for $24 \mathrm{~h}$ are still gluey despite the content of $44.1 \%$ of the insoluble products. The further films heating to 383 or $423 \mathrm{~K}$ increases the content of insoluble products in them and their hardness. At the same time at $383 \mathrm{~K}$ the increase in cross-linking time leads to the increase in both gel-fraction content and hardness.

In the case of cross-linking at $423 \mathrm{~K}$ we observe another situation. At cross-linking time of $45 \mathrm{~min}$ the content of insoluble products achieves already $98.5 \%$ at the hardness of 0.82 rel. units. Further heating (is not shown in Table 2) does not lead to essential changes of both indices. It means that with the increase in temperature from 383 to $423 \mathrm{~K}$ both primary and secondary groups of the synthesized HPO participate in the cross-linking. At $423 \mathrm{~K}$ these groups are capable to react with residual epoxy groups, as well as between each other, leading to the additional cross-linking of the polymeric mixture components. Moreover, HPO molecules have free peroxy groups which can decompose and form free radicals. The formed radicals initiate threedimensional copolymerization of TGM-3 oligoesteracrylate and provide the increase in the amount of insoluble products.

In the case of Mix 2 (without HPO) we also observe the increase of gel-fraction content with the increase in temperature but its value is lower compared with that of Mix 1. Such increase of insoluble products content in Mix 2 is possible only due the interaction between the residual epoxy groups and secondary hydroxy groups which are present and formed during ED-20 resin cross-linking. TGM-3 molecules do not participate in the process of film formation due to the absence of copolymerization initiator in Mix 2. They only plasticize the formed film.

\section{Conclusions}

While using peroxy derivative of ED-24 epoxy resin and PolyTHF-2000 oligoether we synthesized a new oligomer with free peroxy, primary and secondary hydroxy groups in its structure. The catalytic system $\mathrm{BTEACh}+\mathrm{KOH}$ (molar ratio 1:1) was found to be the most effective one for the process. Kinetic investigations vindicate this fact. The presence of peroxy group in HPO molecule is confirmed by doublet of hem-dimethyl vibrations at 1395 and $1368 \mathrm{~cm}^{-1}$; hydroxy group - at $3448 \mathrm{~cm}^{-1}$. The synthesized HPO used as an additive to epoxy-oligomeric mixture based on ED-20 industrial epoxy resin and TGM-3 oligoesteracrylate increases both gel-fraction content and hardness of the obtained films compared with the mixture without HPO.

\section{References}

[1] Samaryk V., Nosova N., Varvarenko S. et al.: Chem. \& Chem. Techn., 2011, 5, 377.

[2] Voronov S. and Samaryk V.: Chem. \& Chem. Techn., 2007, 1, 1.

[3] Bratychak M., Chervinskyy T., Gagin M. et al.: Ukr. Khim. Zh., 2005, 71, 50 .

[4] Bashta B., Bruzdziak P., Astakhova O. et al.: Chem. \& Chem. Techn., 2013, 7, 413.

[5] Bratychak M., Iatsyshyn O. and Kochubei V.: Ukr. Khim. Zh., 2012, 79, 20.

[6] Bazylyak L., Bratychak M. and Brostow W.: Mater. Res. Innovat., 1999, 3, 132.

[7] Milas N. and Surgenor D.: J. Amer. Chem. Soc., 1946, 68, 205. 
[8] Sorokin M. and Lialuyshko K.: Practikum po Khimii i Technologii Plenkoobrazuyushchikh Veshestv. Khimiya, Moskwa 1971.

[9] Antonowsky L. and Buzlanova M.: Analiticheskaya Khimiya Organicheskykh Peroksidnykh Soedineniy. Khimiya, Moskwa 1978.

\section{СИНТЕЗ ТА ЗАСТОСУВАННЯ ОЛІГОМЕРУ \\ З ГІДРОКСИЛЬНИМИ ГРУПАМИ НА ОСНОВІ \\ ПЕРОКСИДНОЇ ПОХІДНОЇ ЕПОКСИДНОЇ СМОЛИ ЕД-24 ТА ОЛІГОЕТЕРУ РОlyТНF-2000}

Анотація. Розроблено методику одержання та синтезовано на основі пероксидної похідної епоксидної смоли ЕД-24 (ПО) та олігоетеру PolyTHF-2000 олігомер, щзо містить у свої структурі пероксидну, первинну гідроксильну та вторинні гідроксильні групи. Вивчено вплив природи та кількості каталізатора, температури та тривалості реакції на швидкість протікання реакції між ПО та PolyTHF-2000. Як каталізатори реакції вивчено бензилтриетиламоній хлорид, гідроксид калію, 1,4діазобіциклооктан та каталітичну суміш, щзо складалася із бензилтриетиламонійхлориду і КОН у співвідношенні 1:1 молі, відповідно. Структуру синтезованого олігомеру підтверджено хімічними та ІЧ-спектроскопічними методами досліджень. Вивчено можливість використання синтезованого олігомеру як активного додатку при формуванні полімерних плівок на основі промислової епоксидної смоли ЕД-20 та олігоестеракрилату ТГМ-3.

Ключові слова: епоксидна смола, олігоетер, кінетичні дослідження, пероксид, гідроксильна група, ІЧ-спектроскопія, структурування. 